Слободан Грубачић

Универзитет у Београду

Филолошки факултет

САНУ

bobo.grubacic@gmx.net

https://doi.org/10.18485/ai_diskurs_pobede.2019.ch1 82.09

\title{
ДИСКУРС ПОБЕДЕ У ИСКРИВЉЕНОМ ОГЛЕДАЛУ ИЗМЕБУ МИТА И МАСОВНЕ ПСИХОЛОГИЈЕ
}

Попут Густава Ле Бона, који је својом студијом Психолоіија масе 1895. године засновао масовну психологију, експресионисту Клабунда опседа важно питање: који емоционални потенцијали се ослобађају код некритичког победничког дискурса? У Клабундовој причи „Пилот“, један ваздухопловни подофицир је шифра за харизматског вођу, а тзв. „наративни скандал“ је брисање границе између стварности и имагинације. Није Клабунду стало само до разоткривања различитих облика нагонски несвесног, већ и до елементарних механизама моћи у стварању чудовишног култа кроз преузимање наивног сна о летењу, познатог још из мита о Икару и Дедалу.

Кључне речи: дискурс победе, мит, масовна психологија, рат, магични реализам.

О неким значајним експресионистима писано је мало с обзиром на популарност њихових текстова код савременика. Тада су их читали сви, баш као у време кад су Шилера учили напамет, с одушевљењем, и не само као знак учености. Однос експресиониста према Великом рату изгледао је код сваког (од њих) другачије, али су га сви једнако славили или мрзели у паничним песмама, 
у драмама пуним исконске таме и бруталне чулности. Политичка клима и грозничави дух двадесетих година, одредили су полемичку и провокативну усмереност њиховог песништва, па тако и специфични guскурс ӣoঠege који се често указивао у искривљеном огледалу.

Једном од најзанимљивијих писаца епохе, Клабунду, аутору романа о йобеgницима и великим историјским личностима, о пророку Мухамеду, о Борџији и Петру Великом, о Наполеоновом генералу Мороу (Moreau) и Распућину, било је стало до психолошког портрета тзв. екстатичних духова и загонетних отеловљења митова створених о великим људима.

А био је, већ у младости, геније провокације. Аутор отвореног писма Вилхелму Другом са нечувеним захтевом да цар абдицира, Клабунд је савремено немачко позориште назвао Помпејима, а себе уздигао у апостола светог театарског тројства. Као персонална унија кабаретисте, аутора гротескних комада и тумача збивања на позоришној сцени, пресудно је утицао на Брехтов „епски театар“ и „ефекат отуђења“. Брехт му је узео идеју, а хтео је да му, од самртне постеље у Давосу, на „чаробном брегу“, одвоји и супругу, глумицу Каролу Heep (Neher), којој је наменио улогу Поли на берлинској премијери Просјачке ойере.

Клабунд је био аутор каквог биографи воле. Луталица који живи на јуриш, склон бурним испадима и насилним решењима душевних конфликата, себе, међутим, није сматрао миљеником среће. Умешан у моралне и политичке скандале у средишту боемског велеграда, потом активиста у данима баварске револуције и контрареволуције, био је најмање једном годишње на ивици смрти. Можда се већ тада, говорио је, његово тело побунило против планова његове главе. Чест гост разних клиника, описао је, још пре Томаса Мана, звездано небо над Ча- 
робним брегом, али и морбидну и декадентну атмосферу у Давосу. Одблесак и његове несталне славе пашће на зидове легендарног швајцарског санаторијума.

Клабундови кратки романи су дуге песме у прози. Идеално би било, каже у једном писму, да је текст написан с таквим напором да се чита с лакоћом. Његов експлозивни стил, необичан у паратакси, вансеријски је експресионистички дискурс, и тиме заправо дотичемо оно што му је донело место у књижевном пантеону епохе. Необична мисао: „Мисли брзо, пиши још брже“, била је мото његовог кратког живота.

Ево, уосталом, чувеног почетка романа о Петру Великом са библијским мотивима апокалипсе, легенде и бајке: „Пјотр се родио. Волга, Дон, Дњепар изливају се на обале. Много људи се дави. Пољски мишеви звижде од страха. Зимско цвеће сагиње своје сломљене главе. Низ дрвеће теку сузе од смоле... Смрзнути лабудови једре на леденим сантама. Зелене очи им сјаје као смарагди. Пао је црвени снег. Ватра је пала са неба из руку Божјих.“"

Због такве симболичне згуснутости пред огромном кулисом времена и простора, једна кратка Клабундова прича о ратном пилоту (Der Flieger, 1916) изазива код читаоца сличну мешавину нестрпљења и вртоглавице: претапањем између фикције и реалности, мистике и физике, магије и - утиска да је ипак реч о рационалном књижевном експерименту.

Прича „Пилот“, наративни конструкт актуалне политичке и људске ситуације, пуна духа и стаклено прозирна, заодева се симболичном одором. Ни парабола, ни алегорија, ни бајка, а све то заједно, ипак је најближа одређењу „анти-бајка“. Говори о повратнику из рата, авијатичару Георгу, опсенару и мађионичару против своје воље, који пролази, упркос крајње сажетој фабули, кроз „стару“ и „нову“ Немачку, кроз старе мисте- 
рије и нову политику. Мада је Клабунд писац и једног романа у духу Тила Ојленшпигела, јунак ове приче је модерни протејски лик, фаустовски опсенар, а не оно што је сам Клабунд у животу волео да буде: иронични, враголасти јунак тзв. доњонемачке „књиге за народ“.

Зато лик пилота има аутобиографске црте, а има га већ и због тога што у причи носи право Клабундово презиме: Henschke. Тај ваздухопловни подофицир, типични лик немачког „повратника“ о коме су писали Ремарк после Првог и Борхерт после Другог светског рата, приказан је као експресионистички Икар. Замишљена као сатира или пародија ратне цезароманије, у којој сваки гест и свака реч имају симболично значење, прича је фрагмент људске трагикомедије саздане на контрасту двају светова: једног могућег и познатог, и другог нереалног, у коме царује нестварна машта, и у коме се варка тумачи као апсолутна истина. Уобличена је притом таквим језиком и дуктусом да се од оне прве не разликује ни по чему. Толико је, уосталом, кратка, да се може навести у целини.

Када се авијатичар Георг Хеншке вратио у родно село на допуст, у сусрет му је пошло све што је имало ноге, а деца су висила на трешњама крај пута којим је морао проћи. Мајка је плакала од среће: „Георги, мој Георги!“, а пастор рече: „Какав божји дар!“

Направише колону која га је достојанствено одвела до трпезе под ведрим небом... Када је вино почело да делује, светина се осмели. Усуди се да пита. „Георги“, рече мајка с нежним дивљењем, „ти знаш да летиш?!“. „Хоћеш ли да нам покажеш?“, запита стидљиво мала Марија. „О“, насмеја се Георг, „па не иде то тек тако. Треба ми авион, машина за летење“. „Има је сигурно у џепу“, насмеја се пастир, „хоће само да нас мучи“. „Машина, је ли то нешто што се навија?", запита најмлађа сестра мала Ана. Јер, сетила се да је Георг једном из Берлина донео малог металног слона. Имао је на себи малу опругу и кад би 
је пар пута немилосрдно окренула на стомаку, слон би почео да тетура, да лупка сурлом у под и потом нагло, попут мале ласице, јури по соби у лудим круговима.

„Не, рече Георг, „немам га код себе, власник је држава“. „Тако значи“, рече један. „Држава. И то је неки проналазак, изум своје врсте“.

„Причај нам нешто о летењу, кажи како се учи“, замоли поносна мајка.

Ту он устаде и сви са њим. Узбуђени, подређени његовој вољи, попут стада око свог предводника. Гледали су увис, чежњиво, плаво небо им испуни очи.

У његовом погледу севну радост тријумфатора, и кад је рекао „Урадићу то!“ - из њега је избио пламен. Скочио је на столицу, раширио руке и размахнуо у правцу сунца. Осетио се тако лак, смешно лак, тло се удаљавало под ногама, руке се расклопише као крила, и он се попут орла вину у плаветнило. Цело село је стајало као једно биће. Видели су Георга како лебди у етеру. Мирно и јасно, далеко и све даље, док се није изгубио из видног поља.

И писац Клабунд се појавио нагло на књижевном небу. Бљеснуо је и - после нагле смрти (1928) - готово нестао из видокруга чак и оне јавности која је хтела да у њему види једног од најбољих младих писаца.

Слично судбини великог броја младих експресиониста, палих већ у првој години рата као у неком жртвеном ритуалу, Клабундовом наративном исповедању била је исписана трагика на челу. Не само због тога што је тек доцније препознат политички набој његових упозорења. Слика политичког опсенарства avant la lettre напросто није имала оно дејство на сцену живота као у средњовековним играма мистерија и миракула. Ипак, већ почетком ратних сукоба, а посебно у оном раздобљу између два светска рата, када су изнова промишљана и формулисана сва становишта о рату и миру, изведена је важна трансформација дискурса по- 
беде у западној књижевности.

Клабундов лик, ваздухопловни подофицир кога окупљени народ слави као весника новог доба, наставља традицију дискурса победе, али - у искривљеном огледалу. Преображен, хиперболисан у циљу гротеске као профане варијанте сакралног вазнесења, он у себи самом садржи противречност. У небеса га уздиже занос: он је лажно приближавање Богу, он је коб целог нарада. Његово фантомско узвинуће јавља се притом у озрачју естетске епифаније. Указује се као сан и спасење у светлу нечег сасвим нереалног и апсурдног.

Колективно ишчекивани херојски узлет очигледан је хокус-покус који по смелости замисли нема себи равног. Бар не као персифлажа, али персифлажа с идејом да главни лик донесе читаоцима - отрежњење. Да учини очигледним илузорни утопизам и беспредметност месијанског језика. У суштини: да попут неких других ликова у немачком експресионизму, дејствује на позорници једног малолетног човечанства, коме се мора принети светлост.

Ако се сложимо око тога да у Клабундовом тексту, уз мноштво референци и ироничне облоге, ступа на сцену и субверзивна дидактичност доносећи тему отпора против репресије, једног отпора који није пуки субјективни рефлекс ратног пустошења, онда ћемо се лакше сагласити са тезом да експресионистичку нарацију можемо посматрати као огромну лабораторију у којој је било много оштроумности и полемичке страсти, и у којој није лако правити разлику између експеримената који воде напред и оних који не воде никуда, при чему се показује да се оно најзанимљивије и најкреативније налази управо у оним зачудним опускулама за која се дуго мислило да не воде никуда.

Већ тада се говорило о кризи приповедања, о нужном 
„ослобађању“ форми и тзв. „намерном фрагменту“. А он подразумева потенцијал разарања и саморазарања. Ликови у Клабундовој причи Пилой су намерно недовршени. Лик мајке се састоји само од суза радосница. Јунак нема ни авион којим се поноси. Детаљно је описана само његова супротност: мали метални слон. Играчка на навијање.

Духовито смањење и увећање самог предмета - од авиона-играчке у џепу, до бомбардера - јесте иронично поигравање са питањем: како припитомити перцепцију читаоца за безазленост погледа, за свет у очима детета, да би се тежња за прекорачењем стварности прелила, типично експресионистички манихејски - у супротним правцима. Или у сасвим свето, или у сасвим профано, као што то бива у месијански и апокалиптички узбуђеним епохама. Притом су коначан резултат - долазак избавитеља, појаву месије - у то време ишчекивала чак три књижевна табора: хришћански, комунистички и нацистички. И сви су, у духу Ничеове књиге С ону сйрану gобра и зла, призивали „људе будућности“, њихове велике и смеле подухвате, како би се укинула „страховлада бесмислености и случаја“, што се досад звала „историјом“.

Клабунд је ту непоновљиво оригиналан, а да тога можда и није био свестан - он долазеће зло заодева светачком одором. Као у драми Кристофера Марлоа о чаробњаку Фаусту и савезнику пакла Мефистофелу: Than holy shape becomes a devil best - изглед свеца ђаволу пристаје најбоље. Клабундов авијатичар, разуме се, има другачији хабитус. Он није ни „анђео историје“ са чувеног цртежа Паула Клеа - онај анђео „гоњен ветром прошлости“ који се тако јако ухватио у његова крила да их више не може склопити. Питање је, наравно, да ли се Клабундов загонетни пиктограм може тумачити и као минијатурни модел целе ирриче о пилоту, али је 
стилом, ритмом, сигурно један од најузбудљивијих наратива целокупне експресионистичке сцене - осим за оне алергичне на магични реализам и бујност маште.

Но та машта је управо начин на који Клабундова прича најављује митску појаву демонског „вође“, који ће се указати као небески пилот у филму Тријумб воље Лени фон Рифенштал из тридесетих година: пружити народу један мит који би истовремено био пропедеутика за свест коју он, као народ, треба да има, и свест коју он треба да има да би био изабран, да би био „спашен“, што значи покоран, паралисан, хипнотисан. О томе је, у $3 a-$ $\bar{u}$ uсuмa $\bar{u}$ opeg $\bar{u} y \bar{u} a$, мислећи управо на немачки народ, Андрић записао: да је један народ најугроженији управо у тренутку кад је цео прожет свешћу о победи (16: 34).

Ако је у неком значајном погледу тзв. естетика рецепције била у праву када је свима отворила очи за разлике у доживљају текста који временом драстично осцилира, онда је то њен увид у брзе и драматичне промене читалачке визуре. На промене у распону од свега неколико година. Још драматичнијим се чини понор који понекад раздваја ауторову намеру и литерарни ефекат. Избегавајући опасност од пада у психологизам, треба рећи да се ауторов став често отуђује од изворних интенција. У многим чувеним песмама постоји и разлаз звучне структуре и песниковог присног хтења. Не мора писац увек бити на висини властите поетике. Психологија стваралаштва често са неодмереним задовољством истражује примере у којима се трагични дискурс преокреће у несвесну, нежељену комику.

Прича о пилоту настаје у трећој години Великог рата, још док је барут промукло говорио на ратиштима, као плод Клабундовог несумњивог преумљења. Као резултат, могло би се рећи, јасне пацифистичке „метаноје“. Лежећи под окриљем самоће и бола у санаторију- 
му у Давосу и пишући, као и увек брзо и лако, роман са знаковитим насловом Болести (Krankheit, 1916), његово подозрење почиње да добија облик извесности када у затворени свет „чаробног брега“ стигну нови шокантни извештаји о догађајима на европским ратиштима.

Гледајући на „земне послове“ с алпске висине, из визуре некад највише хелветске кантоналне престонице, он јасно види да Европи предстоји и много тога неизвесног, али да јој сасвим сигурно предстоји брза смрт. У томе је и симболични смисао питања са којим почиње прва реченица романа Болес $\overline{\mathcal{u}}$, написаног за само два месеца: „Ви сте дакле дошли овамо само да бисте умрли?“.

Сада је, наиме, Клабунд и сам постао свестан колико се заплео у своје рођене опсене и варке. Схвативши да реалну историју више не подржава никаква илузија, никаква метафизичка инстанца, у њему се, по свему судећи, згаснуо последњи трачак недоумице. Првобитно одушевљење преобраћа се у осуду насиља и националистичке реторике. У радикалан облик немирења с постојећим. На њега је сада могла да се примени дадаистичка девиза Хуга Бала: „Ја ипак нећу толико изгубити главу да, док падам, не проучавам законе слободног пада“.

Другим речима, отпор и осуда се у Клабунду бу̀де свесно, а не по самовољи неког тајанственог трептаја тренутних емоција. Одлучан да преживи стихију која је брисала појединце и народе, одлази на југ, у швајцарски Тесин. Премда и даље „оптерећен вишком немачке душе“, придружује се немачким емигрантима повезаним с организацијом Monte Verità из Асконе. Тамо је, у вили Neugeboren, у месту Monti sopra Locarno, боравио с мање познатим писцима који су били на маргини тадашњег књижевног и друштвеног живота, али и с елитним интелектуалцима и ауторима: прозаистом Херманом Хесеом, песникињом Елзом Ласкер-Шилер 
и филозофом Ернстом Блохом.

Радикализам Клабундове приче представљао је одговор на реалну опасност ратне еуфорије која би могла поново да захвати немачко становништво. У тој историјској претпоставци, дакле, с ону страну естетског, крије се и полазиште оног дела експресионистичког покрета што стреми духовној обнови и одрицању од једног смрти допалог света који се предао обожавању силе и моћи. Отуда се и „погонска сила“ пилотовог вазнесења мора подједнако тумачити и разорним силама заноса и тежином ратне стварности: он је усковитлан нечим што долази као предосећање земљотреса. Као наслућивање катаклизме која ће га катапултирати у небо.

Клабундов авион пун илузија везан је, међутим, ременом историјских чињеница. Не може бити случајно што се управо поводом авиона јављају наизглед баналне формулације, а све оне заједно, опет, као дериват много ширих, животних искустава. Најочигледније тамо где се, поред авиона, и сама gржава доживљава пејоративно као нечији изум, односно „проналазак“ своје врсте.

Нису то, ипак, баналности. Клабунд овде алудира на добро знану политичку тезу која је код Немаца била у оптицају још од 18. века. „Држава је проналазак“, устврдио је, уводећи управо ту формулацију у научну расправу, историчар и просветитељски либерал Август Лудвиг фон Шлецер (Schlözer). У својој књизи Ойшие gржавно ираво, Шлецер је написао и чувену реченицу: „Људи су државу изумели за своју добробит, као што су пронашли железну касу“. Стављајући у друкчији контекст Шлецерову реченицу о „држави као изуму“, Клабунд хоће да Шлецера разуме у новом кључу. Хоће, штавише, да га разуме боље него што је он са̂м себе разумео.

Колико је много идеолошког пртљага, колико је прокријумчарене спекулативне робе било укључено 
у наративне експерименте експресионизма, то се показује и на овом наизглед скривеном примеру. Аутор, дакле, у само ткиво приче убацује однос војске и државе, приповедања и оног о чему се приповеда, а да притом нигде не посегне за неким стручним говором, па тако ни за правничком терминологијом.

Просвећеном професору Шлецеру, савременику Имануела Канта и заслужном теоретичару Опште историје, државе и права, нису, наравно, биле нимало блиске романтичарске идеје о „древном огњишту племена“. О томе речито говори жестока полемика са Хердером и његовим следбеницима. Њихова теза о биолошкој, органској повезаности етноса јасно је показивала да и држава може постати сабирни појам у којем најсупротније и најудаљеније ствари налазе свој заједнички именитељ. Некадашњи социолошки бестселер Фердинанда Тенијеса (Gemeinschaft und Gesellschaft, 1887) поновиће ову контроверзу, разликујући „механички друштвени агрегат и артефакт“ од „живог организма“ заједнице.

У очима угледних научних првака Клабундовог доба, пак, какав је био професор политичке економије Вернер Зомбарт (Sombart) - који је своје књиге у заносу политичког романтизма посвећивао Млаgим јунацима йамо gалеко исиреg неиријайеља (1915), уверавајући их да „живот није највећа вредност“- држава је значила и нешто друго. Нешто много веће и много више. Уједињена спонтаним самоукључивањем народних маса, представљала је метабиолошко, gуховно живо биће.

Али и сам пилот, експресионистички Икар који нестаје у хармонији звезданих сфера, у етеру „мирном и јасном“, јесте рана антиципација масовне психозе о којој ће писати Елијас Канети у књизи Маса и моћ. Клабундово село је велики свет у малом. Монада и огледало политич- 
ког космоса с далекосежним литерарним и теолошким конотацијама. Оно има својства сценске поставке: читав појавни свет постаје позорница за пародију свечаног и узвишеног, налик на визионарски тријумфални поход учесника у идеалним, олимпијским скуповима. Однос између гомиле и њеног идола убраја се, иначе, међу најтајанственије загонетке живота. Око јунака ове приче - и јунака из рата - народ се окупља попут стада око свог предводника: „Он устаје и сви за њим“. И сви дишу као један, „подређени његовој вољи“. А кад небески огањ уђе у живо тело тог небеског ратника на допусту, кад осете ватру у његовим речима, они виде и оно чега нема.

А чега има? Визија „вође“ који лети у небо нуди и сатиру и пародију ратне цезароманије. Она се манифестује као инсценација заснована на ефекту, на ритуалном чину у служби сугестивног политичког и идеолошког утицаја. То значи да је судбина пилота као изабраног појединца на путу да се преобрази у трајни образац, другим речима: у мит. „Масовно слепило“, које га прати, описано је доцније у у новели Марио и мађионичар (Mario und der Zauberer, 1929) Томаса Мана, у Канетијевом роману Заслейлене (Blendung, 1935), у Броховом незавршеном делу Зачараваюе (Die Verzauberung, 1935) или у Јингеровом роману На мермерним тиииицама (Auf den Marmorklippen, 1939), у коме доминира дијаболични лик Врховног шумара.

Суштина заноса је вера у чудо, а тај се мотив јавља и код Андрића, у причи о Томи Галусу, заједно са симболом „непокретног звона“ које ће својом звоњавом „покренути свет“. И ту је пламтео патос који се без двоумљења опија највећим хиперболама: Галусов „смртоносно моћан занос“ прати неко чудесно „осећање моћи без граница“. Осећање које се може 
свести на малобројне тренутке екстазе између живота и смрти. Говор Клабундов, међутим, није распевани, барокни, него церебралан, гротескни дискурс.

Гротескна је и она тријумфална опијеност у самом књижевном лику: у његовим очима сева „радост тријумфатора“. Јединственост слике, пак, у којој из њега избија пламен заједно са одлучно и беспоговорно изговореним речима, достиже онај степен који нам дозвољава да јој припишемо помало језовиту естетску лепоту. Пилот личи на гутача пламена, речи му обавија ватрена аура. А сви знамо за сличне преображаје: сви смо чули како је пророк Илија одјездио у небеско плаветнило на пламеним колима. Напустио је земљу у виду ватре.

То је само један у низу Клабундових наративних трикова. Фантастична иконологија постаје моћан облик да с ироничном лакоћом визуелно изрази вербални занос. Он је у служби естетизације једне визије чији средишњи део је култ вође. А он већ није само човек. Он је Моћ. Превазишао је људско бивство - преступио границу. У том тренутку, наравно, лик авијатичара Георга Хеншкеа подсећа на ликове из старије историје књижевности. Највише можда на лик „магнетизера“ Албана код романтичара Е. Т. А. Хофмана.

Попут Гистава Ле Бона, који је својом студијом Психолоїиј масе 1895. године засновао масовну психологију, експресионисту Клабунда опседа питање: који емоционални потенцијали се ослобађају приликом некритичког победничког дискурса? Његов ваздухопловни подофицир је шифра за харизматског Вођу, а тзв. „наративни скандалон“ је брисање границе између стварности и имагинације. То се уистину одвија нагло и неочекивано, баш као што је Георг у тренутку жртвује своју нормалност, своју обичност, и преузима на себе надземаљску мисију. Све је очигледније да Клабунду није било стало само до разоткривања различитих об- 
лика нагонски несвесног. Он би да проникне у елементарне механизме моћи и стварање чудовишног култа кроз преузимање наивног сна о летењу, познатог још из мита о Икару и Дедалу.

Однос мита и савремене књижевности приближава нас питању које, најблаже формулисано, гласи: шта се уопште постиже скидањем митолошких и теолошких представа са њиховог трона? Њихова преквалификација доводи до епохалне промене. Оне се изједначавају са „празним именима“ која немају стварне носиоце као што су „Пегаз“, „вила“ или „једнорог“ - са сликама, уосталом, без којих књижевност не може да опстане. Поставши саставни део једне нехришћанске естетике, хришћански мотиви су овде употребљени за уметничке ефекте попут Рилкеових „невидљивих анђела“ у Девинским елеілјама. Сви су они, мање или више, преиначени у име једне више, уметничке истине, пред којом је стварност, како је говорио Карл Краус, „само оптичка варка“.

На тренутак би се могло помислити да ти мотиви само прате нашу уходану рутину именовања културних навика. Да као дубоко укорењене навике ума и наслеђене концептуалне метафоре претрајавају као пуки йровоgниu, значења, док у ствари служе опису стварних, коренитих животних промена у каталогу постојања. И то једног ирреображеной начина постојања. Оног о коме се говори у метафорама на целој скали живописних литерарних мешавина. Мит, хералдика и басне сведене су овде на своје врхунце с невероватним додатним перформансом који, између осталог, од човека прави биће које бљује ватру.

Алегорија или пародијска реминисценција? Ако би се посветила пажња другој претпоставци, онда би се јавила потреба за допунским расветљавањем места која нису дословно присутна у тексту, али су присутна кроз преокретање, кроз инверзију слика и стилских об- 
разаца из арсенала романтичарског дискурса, који је, на пример, налагао да све мора да буде йлаво: не само небо и стапање појенца с космичком хармонијом, већ и боја анђела, сви облици фатаморгана и снова. Блиска Клабунду, песникиња Елза Ласкер-Шилер је у трећем поглављу књиге Moje Cрие (Mein Herz) ову драстичну инверзију романтичарског наратива сликовито применила на своје песништво: „Била бих вечити анђео, да нисам Луциферова сестра!“

Као да све иде у прилог претпоставци да је у причи о пилоту реч о прећутној, свесној или несвесној расправи са Фридрихом Ничеом који је себе назвао Антихристом. Заправо о немилосрдном урушавању идола натчовека, његове виталности и - у исти мах - његове бестелесне духовности. Клабундов натчовек је нешто као грчки hyperánthrōpos. У нечувеној стилизацији и самоинсиенацији, дрзак, безмерно надмен, пилот који носи име писца, види себе као спаситеља и владара света, поставши, на тако бизаран начин, извршитељ Ничеовог тестамента.

Стога би неправедно било прећутати у којој мери је на то могла утицати и естетика самопроглашеног „антихриста“ Фридриха Ничеа, тог „земљотреса столећа“, како га је, говорећи у име целе генерације одушевљених експресиониста, назвао песник Готфрид Бен. Аутор књиге о Истинии и лажи у изванморалном смислу, који је хришћанство назвао „платонизмом за народ“, сматрао је, наиме, владавину разума и логике у уметности највећом запреком у развоју цивилизације. У духу своје „артистичке метафизике“, знаменити иморалиста је то и поткрепио често цитираном сликом: истину је, наиме, прогласио за „покретну војску“ метафора, метонимија, антропоморфизама.

Из тога се онда морао извести закључак да није важно јесу ли неки догађај или његова инсценација за- 
иста истинити у правом смислу речи, с обзиром да је човек заплетен у клупко лажних појмова, вештачки додатих значења и њихових интерпретација. За уметност то важи већ по дефиницији.

Сетимо се: у епохи естетицизма на прелому векова - када уметност више није имитирала живот, већ је живот имитирао уметност - филозоф Фајхингер, творац бикционализма, учинио је све да категорији естетског привида врати некадашњи углед и пуну меру значења. Тврдио је да је фикција ефикаснија од истине. Уметност није тек нека врста „корисне фикције“ као што су то „атом, Бог или душа“. Она креира митологеме и моделе који су за виши духовни свет важнији од стварног живота (Die Philosophie des Als Ob, 1911). Историја естетике је, знамо, имала срећу да се на ове идеје одмах надовежу расправе некада утицајног историчара и теоретичара уметности Конрада Лангеа о бићу уметности (Das Wesen der Kunst). У њима је плашт свесног самозаваравања покривао обе стране: и принцип уметничког стварања, и читаочеву рецепцију.

Али су те идеје са једнаком пажњом биле разматране и у етици - код једног Маркезинија (Giovanni Battista Marchesini, Le finzioni dell'anima, 1905), на пример као прагматична вредност или практична педагогија. Анархиста Сорел је на супротној идеолошкој страни позивао на стварање нових митова за револуционарне потребе. На отворену инструментализацију уметничких наратива који могу послужити као показни примери. У добу без богова, говорио је, митови ће заменити старе религије из којих „еманира машта“.

Све се мање зазирало од свођења фантазије на утилитерне императиве. И све више су психолози, кроз истраживање несвесног, говорили о феномену „двоструке свести“. У њој појединац - прецизније: његово 
саморефлексивно Ја - негује илузије, иако зна да су нереалне. Више се није цитирала Колриџова досетка да читалачко искуство подразумева „свесну суспензију наше неверице“. Да се читање своди само на willing suspension of disbelief. А то другим речима значи: на лагодан начин да се у потпуности препустимо уживању у доброј књизи. Професор Мајкл Сејлер (Michael Saler) je упозоравао да се, заузврат, све више говори о тзв. „вишеструком сопству“. О томе да сваки појединац има gвa мозї $а$, који се „међусобно посматрају и контролишу, забављени својим наизменичним непредвидљивостима“.

Из тога се онда извлачи закључак да је у двадесетом веку могуће установити успон нечега што се може назвати ироничном имаїиначијом, која дозвољава да људи, не само читаоци, истовремено живе у једном измаштаном и једном реалном свету.

Сви знамо шта је онај силовити занос, који нас, збуњене и опчињене, обузима када нам та двострука свест омогући да симултано доживимо илузију и дезилузију. Али пресудна је у свему томе чињеница да сам фикционализам не представља ескапизам. Није реч о бекству, напротив. Филозофи и психолози су коначно уважили да се имагинарни и стварни свет међусобно конституишу. Да фикција, штавише, омогућава ревизију стварности.

Уметност - лаж која помаже да се спозна истина - налази се код Клабунда, сходно таквом тумачењу, у служби сугестивног идеолошког утицаја и култних ритуала који укључују и сам технички развој. Могли бисмо, дакле, без већих потешкоћа, тезу о фикцији ове врсте оправдати уметничким разлозима. Сама концепција уметничке истине у књижевном тексту несумњиво је „лажна“, али је, према парадоксалној замисли Клабундовој, у свом деловању на читаоца уједно толико претерана да може бити дискредитована као одвећ 
тенденциозна с обзиром на реално животно искуство. Сада се као једина тешкоћа поставља питање како је уопште могуће уклопити тако комплексан проблем у један сажет, а ипак кохерентан наратив. То је, такође, пробни камен његовог тумачења.

Жанровски гледано, кратка прича се по дефиницији сажима и згушњава у појединачан случај, у фрагменат. У нестварности изоловане поенте - узлета у небо, који личи на привиђење - предочава се и целина приче о пилоту. У том смислу би се зацело могло рећи да су и Клабундови романи остали недовршени. Фрагментарни. Они по много чему личе на допадљиве рушевине амбициозних пројеката, који носе у себи како знакове раскоши, тако и брзине с којом су настали. Син апотекара и несвршени студент фармације, Клабунд је, међутим, умео да дозира своју нарацију у смислу своје поетике и владајућих дискурзивних модела.

С пуним правом се, такође, у експресионизму помиње принцип напоредног приказивања. Треба га, међутим, разумети као нарочит йриниий безузрочносиии. Реч је о набрајању ствари које наизглед немају никакве везе, дакле о једној на први поглед ничим изазваној, необразложеној ужурбаности која кроз неповезаност репродукује збуњујућу слику савременог света. Њена речита недореченост има за циљ да живот и свет представи као неред, хир и опасност. У њој су експресионисти видели посебну драж. Она је била бекство у „божански несклад“, била је „удаљеност од досаде“, од празног савршенства. „Савршенство је идеал осредњег духа“, говориће и „човек без судбине“, млади Мирча Елијаде.

Преломи, скраћења, фисуре; наговештаји, пропламсаји смисла; мистичне епифаније, учешће у космичким енергијама; претварање појединаца у масу - све је то део наративне стратегије чији циљ је само један: да се 
инсценира стварност која се заснива на нестварном ефекту култа вође и његовог вазнесења. Свако друго настојање да се у ту стварност унесе неки склад или поредак који има свој почетак, средину и крај, представљало би суштинско изопачење и карикатуру онога што је већ по својој природи хаотично и безоблично.

Необично наглашавање детаља оставља отворене границе према непознатом, ствара острва приповедног језгра у простору ћутања у којем се можда још увек, скривено, само као указивање и слутьа, наговештава смисао. Помоћу наративног трика који прецизне реалистичке слике повезује у њихова метафоричка спајања, фрагмент се онда испуњава вишезначношћу. Томе иде у прилог одустајање од филозофских и тематских артикулација, и наглашавање сценске стилизације, амблематике и реторике. Сличан поступак ћемо наћи у прозним скицама експресионисте Готфрида Бена. А он ће, у потресном говору над отвореним гробом свог „најстаријег пријатеља“ Клабунда, рећи да се великом књижевном делу овог уметника - „ове лу̀де,

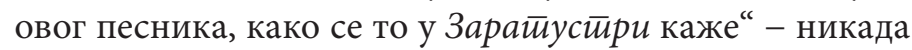
неће држати посмртно слово.

Но да ли се то догађа и због тога што су код Клабунда сједињене различите категорије које означавају стварно и бајковито? Нема сумње. Будући да су животне истине дубоке, дубље од њиховог испољавања, авангардни кратки наратив с невиђеном слободом комбинује елементе који припадају разним дикурсима - као да на малом простору тражи заједнички именитељ свих ствари и свих појава.

Извођење бајке на психолошку позорницу може, према општем очекивању, имати и нешто другачије значење. Тако дубинска психологија држи да бајка, осим симболичког и метафоричког уметничког потен- 
цијала, крије исцелитељску моћ и драгоцен педагошки ефекат. Да ли то онда значи да је Клабунд, управо користећи елементе анти-бајке, најубедљивије разоткрио култ вође? Немачки експресионизам је, додуше, неговао крајности, поремећај равнотеже, демонску или инфантилну провалу безобличности. Али, да ће ићи тако далеко? Да ће посегнути и за сликама које би пристајале раздобљу „агоније романтизма“?

Ту се зато мора размотрити и сам чин идентификације свих ствари и појава, пре свега, идентификације читавог народа са пилотом. Народ је овде колекииивни синіулар. „Цело село је стајало као једно биће“, каже се у тексту. Но, ако се сам догађај одвија у тако малој средини, нарочито погодној за подвајања, за нарцизам малих разлика, мора се поставити питање: Каква је природа тог прећутног идентитета? Да ли је реч о пукој заслепљености и лажном самопрепознавању или о продубљивању митова који се враћају у свест као бесконачно огледало?

Сама чињеница да се сви присутни, скупљени и уједињени, поистовећују с алегоријски осветљеним јунаком приче, са личношћу лидера која изражава дух народа, говори да је појам идентификације сложен. Он овде не подразумева само феномене пројекције или сублимације у контролисаним психолошким ситуацијама. Он укључује и једно наглашено социјално, и у том смислу такође и једно идеолошко понашање. Али понајпре подразумева присуство ефикасне харизматске идеје која прочишћава народно тело.

Физика је научила пилота да лети. Метафизика га је научила да превлада време и простор. А кад се то у књижевности доказује као нешто сасвим реално и могуће - шта нам се намеће као закључак? Свеједно да ли код Клабунда, Кафке, Бекета или Јонеска - очигледно 
је да у дискурсу фантастике по правилу настаје и једна посебна врста „фотографије непостојећег“. Такве слике се суштински не разликују, али су разлучиве - за нашу анализу. Оне више не пружају репродукције неког реалног, чињеничног стања, већ тако рећи прецизне фотографије непостојећих, фантастичних догађаја.

Управо су фантастични, магијски догађаји описани у уметности авангарде навели једног утицајног немачког историчара уметности да напише прву књигу о „магичном реализму“ (Franz Roh: Nachexpressionismus. Magischer Realismus. Probleme der neuesten europäischen Malerei, 1923). Појам магичног је из сликарства пренет на књижевност. „Намера ми је била“, истицао је овај утицајни уметнички критичар, пријатељ Швитерса, Гроса и Макса Ернста, „да магија замени појам мистичног, који нимало не одговара свету који се приказује у уметничком делу“. Његов текст је превео Хосе Ортега и Гасет (Ortega y Gasset) и одмах покренуо књижевну моду. На тим основама настаје, знамо, и латиноамеричка фантастика: Габријел Гарсија Маркес, Хорхе Луис Борхес, Алехо Карпентијер - фантастика свакодневице, el realismo magico који траје и данас. Одавно се, међутим, схватило да је то појава која, временски и просторно, надилази оквире нечег тренутног и епизодног. Одавно је, такође, нарочито у Немачкој, у оптицају фраза да та „ципела одговара многим стопалима“.

У том случају се проблем може сагледати из другог угла. Ништа нас, на пример, не спречава да дискурсу магичног реализма прибројимо и позни Јингеров роман Сйаклене йчеле. С друге стране, непорецива је сличност која магијску машту повезује са надреализмом: укидање реазлике између реалности и фантазије; чудесно у обичном, свакидашњем; мешавина precision realiste i atmosphere magique. Њена суштина није разумљи- 
ва ако се поглед држи стално прикован за једног писца. Но ако већ призивамо главне свеце у календару литерарних побуна и промена, онда је занимљивије лоцирати наратив Пилой $а$ негде између других експресиониста и аутора Процеса.

И код Клабунда и код Кафке су историјска стварност и догађаји уздигнути на симболичну раван, али је Клабундова проза динамичнија; нема дугачких описа. Код њега мали човек постаје митска фигура, док су код Кафке митске личности Одисеј, Посејдон приказани као мали, обични људи. Чак се и Букефал, коњ Александра Великог, појављује у лику „угледног адвоката“. Ипак, поетолошки циљ им је истоветан. То је увек след слика које запрепашћују, али које су међусобно повезане неочекиваном аналогијом. Кафка рачуна на шок, текст је за њега „секира што разбија лед у нама“, док с друге стране Клабунд екстремним претеривањем буди читаоца из његове „грађанске хибернације“.

Постоје чврсти разлози за још једну тезу. Нема у раном експресионизму и футуризму писца и мислиоца који није фасциниран техником. „Ми авијатичари духа“, вели Ниче једном у намери да велича слободу мишљења која у бескрајном небеском елементу налази нове путеве. Лет аеропланом обећавао је интензивнији живот, његова „виша перспектива“ често је митизирана и стављана у религијске релације. Има тога и код Милоша Црњанског, дугогодишњег уредника часописа Наша крила, код кога се хетеротопија авионске кабине јавља у склопу узбудљивог динамизма новог времена: „Авион, то је једна фотеља од алуминијума, мирна и дивна над земљом, из које се гледа на небеса“ („Надземаљска лепота Србије“, Полит̄ика 1923, Време 1925).

Чак шестиорииа идентичних, униформисаних пилота појављују се одједном у трећем чину експресиони- 
стичке драме Просјак с озбиљним, укоченим изразом на лицу, загледани у неку вишу, мистичну, само њима видљиву инстанцу. У овој драми Рајнхарда Зоргеа (Sorge) - који ће погинути у рату пре но што сазна да ће та униформа бити последње свечано одело немачке војске - пилот је приказан као идеалистички тип новог човека, чији долазак ишчекују генерације. А ишчекиван је са тако великим нестрпљењем, да је у самој драми - умножен. У брзој измени реплика, налик на іоворне ауйомайе, они се и не представљају као ликови, већ преузимају функцију колективног наратора, при чему сваки од ових шест пилота изговара патетичне шифроване поруке. Прате их „звуци оргуља“ што „ломе облаке небеским зрацима“, призивајући мит о Дедалу и Икару.

Но да бисмо избегли примедбе о искључивом праву на селекцију примера, навешћемо и патетични случај једног шпанског писца. Ко без предубеђења чита авангардну литературу, тај одмах примећује да је песник и критичар Гиљермо де Торе - представник хиспанског „ултраизма“ који је изашао на глас као аутор једне од најпознатијих историја авангардних књижевности - отишао, као млади песник, најдаље у својим изливима емоција. Закорачио је снажно у симболику непредвидивог, наднаравног, шокантног - и еротичног. Заљубио се - у елису авиона: „Үо quiero por amante / La helice turgente hydro-avion ...."

То је управо место на коме се морамо вратити Клабунду. Јер, међу емфатичним Клабундовим Војничким иесмама (Soldatenlieder, 1915) објављеним на почетку Великог рата, налази се једна која има исти наслов као и његова прича - „Пилот“. Још увек заљубљен у ерос смрти и разарања, припадник генерације оптужене за призивање апокалипсе, овде не види њихову метафизичку основу, начело зла. Види само снагу која се опире кобном развоју модерног доба. Зато не признаје ни тра- 
гику смрти ни песимизам Шопенхауера. И зато је имун на болести које се зову милост и саосећање. Његов пилот није само инкарнација неког тобоже вишег етичког начела недоступног обичном човеку. Показујући чудну наивност која нимало не личи на дечју безазленост кад чупају руку или ногу својој лутки, он се по свему приближава Маринетијевом идеалу новог, „механичког“ човека: tipo non umano e meccanico:

Дрхти сребрни змај, / поскакује, успиње се и диже - / Нека те богови ветра воле..../ Мотор бруји./ Мотор пева /.../ Ручица горе! Нек падну бомбе / у катакомбе ... / Три хиљаде метара... / Пред тобом нестаје свет / Сад нестајеш и ти, велик у етеру / ко златна планета. / И трагом звезда, / већ изван времена, / Летиш у бескрај и вечност.

Узјахујући „сребрног змаја“, огрнут звезданим, симболично-алегоријским плаштом, праћен митским „боговима ветра“ у овој архетипској слици, пилот је заправо предмет и жртва нечувене естиейизаиије райа. Својеврсна химна уништења која га уздиже заносно и готово обредно, слави га као „златну планету што нестаје у етеру“. Као стравичну еманацију зла у духу еуфоричног узвика „Рат је леп!“ Филипа Маринетија, који је, проповедајући „хигијену света“, сладострасно прожет морбидном и застрашујућом чежњом за убијањем у сезони смрти. Чежњом снажнијом од свих земаљских обзира, упоредивом само с „елисом која лепрша као застава на ветру“ (Figaro, Paris 1909).

Дадиста Хуго Бал видео је у свом Бексивву из времена преображај материјалног у духовно. Машина оживљава материју: „Die Maschine verleiht der toten Materie eine Art Scheinleben. Sie bewegt die Materie. Sie ist ein Gespenst“. Њен пилот је, међутим, њена супротност: он је неумољиви и незасити непријатељ живота, 
протагониста смрти, њен најоданији војник. Лепота рата искупљује зло, осветљава га као култ и несумњив феномен скривених антрополошких константи које долазе из прадавнина.

Клабунд се убрзо разочарао. Разорна експлозија деструктивних сила означила је крај илузије о лепоти машинског света. Метафизички патос је нагло нестао. Ослобођен повеза на очима, писац прозног „Пилота“ постаје пацифиста. Он види себе као пророка Јону кога је библијски кит Левијатан поштедео и избацио на обалу након што се покајао. Све ће оштрије нападати идеологију националсоцијализма, нарочито

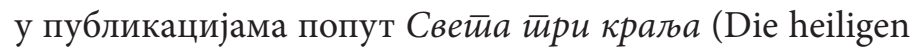
drei Könige, 1925). На позадини тог искуства, Клабунд развија своју теорију о Злу и пише истоимену кратку причу као јасну контрафактуру уз наведену песму.

Али пише и велики број антиратних песама. Из једне у другу, из песме у песму, осећа се Клабундова порука да је рат највеће страдање, највећа мука и провера људског рода. Узори су му Франсоа Вијон, Хајне и нарочито Ведекинд, чији текстови својим необичним ефектима нуде мешавину старих мистерија, луткарског позоришта, моритата и баладе.

Међу њима се издваја Балаgа заборава (Ballade des Vergessens) која 1927, у време јачања новог милитаризма, упозорава подсећањем на последице немачке ратне еуфорије из предратног периода. Последице које ће се, каже, сигурно поновити. Рат је, наиме, био завршен, а већ се назирала нова ратна опасност. У том смислу би се могло рећи је песник био „видовит“, верујући да је нови рат пред вратима, „сасвим близу нас, ако не и у нама“, и да ће бити много разорнији и већи од Великог рата. 
Нови рат неће бити праћен херојском позом, / Доћи ће с отровом и гасом. / Друкчији од ваших снова, без сабље, / право из вражјег лонца. / Нећете га тако, и не тако лако, / заборавити....

Филозоф Макс Шелер, који је умро у истој години када и Клабунд, прошао је кроз идентично искуство. И за њега је, на почетку Великог рата, тај хераклитовски „отац свију ствари“ значио нешто елементарно, нешто што „прочишћује“, што у болу рађа нешто ново. Стога је, у свом Генију райа (1915), истицао његов позитивни значај: „Рат избија“, тврдио је - баш као што из Клабундовог пилота нагло „избија ватра“. Уследиће суочавање с ужасима ратних страдања, а потом конверзија као свесни или несвесни одбрамбени механизам путем којег унутарпсихички сукоби добијају симболичко вањско значење.

Шелерову душу, као и душу Клабундову, раздирале су, дакле, две опречне тежње, са битно различитим духовним импликацијама. Шелер ће надаље уважавати борбу и сукобе као антрополошку константу човека, али не и рат. Настају његове чувене „филозофске бројанице“ које, као у Хесеовој Иірри сйакленим иерлама, изводе праве симфоније пацифистичких погледа као последњем немачком метафизичком уточишту пред насиљем историје. Те формулације ће погодити животно осећање свих оних који су се после катастрофе нашли међу рушевинама.

Гледајући у време као у отворени хоризонт, Шелер ће објаснити шта доноси река времена - све саме људске поразе, све саме мале растанке, све мале или велике смрти. Он ће оправдано указивати и на „систематску побуну инстиката у човеку новог доба“. Зачуђен, заплашен, упозораваће да сваки рат износи на видело оно што је 
скривено у човеку: он премерава обим, распон људске природе. Говориће и о бездану у коме се налазе недокучиви темељи људске природе, али ће за собом повући и неке високопарне тонове и неочекивану естетизацију друштвеног живота. Обновиће, патетично али доброхотно, онај стари немачки, кантовски сан о „вечном миру“ и јединству људског рода, оне фантазије о панлогизму света, о помирењу на крају времена, о неопходном наставку изградње Вавилонске куле.

Ту је заиста реч о великој противречности. Јер, цело раздобље европске Нове сииварносиии у коме филозоф Шелер сада пише, у суштини одбацује све еуфоричне крилатице: одбацује лепоту као класну предрасуду, уместо утопије форсира стварносну прозу, естетику ружног, у чему види пресликану метафизичку беду човека. Дискурс општег пропадања мирно коегзистира с ревношћу обнове. Крај историје и њен нови почетак, „једино могући пут обнове“, као да чине два пола који се на необичан начин, убрзано и скоро драматуршки, смењују или надопуњују, без синтезе - као пуко стање ствари. Савременицима Вајмарске републике то је изгледало замршено и збуњујуће, као низ неспојивих екстрема. Као нихилизам крцат супротностима: равнодушност и очајање људи, исповедање апсурдног, феноменологија зла.

„Човек уопште није добар“, певало се у Брехтовој Просјачкој ойери. Био је то глас великог, историјског разочарења, глас једнако продоран и резолутан као и у најизвођенијем комаду на немачким позорницама - у Клабундовом славном драмском тексту Круі креgом (1925), којим се Бертолд Брехт инспирисао за још славнију драму Кавкаски круі креgом (1944). Патетику је охладио цинизам; занос је гасила иронија; ратну еуфорију - пацифизам.

„Астрологија историје“ Освалда Шпенглера и Хајде- 
герова „теорија бачености човека у свет“ заступале су, по речима једних, фатализам који одустаје од етичких идеала. Зачуђујуће велики број књига двадесетих година имао је патетичне и празне идеолошке наслове типа Норgијски човек и суgбина. Такве судбинске тезе нису заступали само академски мандарини који су сањали о некој нордијској Хипербореји. Већ поменути песник Готфрид Бен заступао је мишљење да ће књижевност преузети функцију религије и политике: „Песништво ће поново остварити оно примарно антрополошко јединство

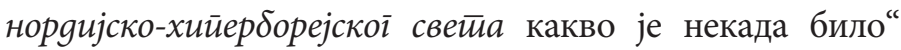
(Börsenblatt, 6. 1. 1934). Други песници су, опет, гладни интензитета, у књижевности захтевали „дивље“, аутентично искуство, о коме се неће писати без највећег узбуђења.

Суштина ових контраста крије се већ у самим насловима. Клабундовог Натчовека прати Фаладин роман с насловом Мали човече - ийа cag? (1932). Очигледно је да се ту везују елементи који се иначе не би стапали, али се зато, после хлађења, лакше растварају у анализи. Па ипак, чим се проблеми преведу на когнитивне појмове семантичких промена, одмах се поставља питање које се може односити и на мање литерарне сегменте. О чему је онда реч у причи „Пилот“? На први поглед је сигурно само то да прича садржи одјек, тачније: одсев хришћанске гностичке метафизике која се пита: откуд зло? Unde malum?

Клабунд, међутим, не даје генезу зла, њему је стало до његовог симболичког раскривања, до симболичке манифестације. Са тог становишта се можда не чини погрешним утисак да је реч о нешто скромнијој амбицији. О наративном покушају да се „људско, сувише људско“ допуни злом као неодвојивим делом conditio humanae. Ca друге стране, тешко би било поверовати да се у Клабундовим алузијама крије слика колективног излета у небо тако званих уранойолити $а$, чије боравиште је негде на Млечном 
путу. Или да је посреди само „лажно преузношење“, како је то звао филозоф Мозес Менделсон у 19. веку.

Какав завршни суд можемо донети о успелости ове приче: моралној, идејној, жанровској, пре свега уметничкој? Као прво, неизбежна су поређења. Попут експресионисте Вилхелма Клема, заступника теорије о неопходности „магичног бекства“ и аутора славне збирке Gloria! (1915), који је у песми „Битка на Марни“ сковао концизне стихове налик на афоризме (Моје срие је велико као Немачка и Франиуска зајеgно, иробушено свим мецима светиа) - Клабунд је одабрао једнако ефектну кратку (прозну) форму која преузима постојеће мотиве, ликове и моделе победничког дискурса, али их пародијски стилизује и срачунато преводи у раван неискрене патетике. Замишљена је као морализаторска психологија. Тачније, као уметничка фикција искоришћена у сврху корекције доминантног погледа на свет у тренутку и атмосфери општег йомрачења света.

Друго, њена особена динамика, њена снажна литерарна, експресионистичка дисторзија омогућава истинску критику илузија свести. То је критика масовних ритуала с обичајима у духу Армије спаса. Узвинуће, „вазнесење“ Клабундовог пилота изазива „свети страх“: све постаје узбуђење, опчињеност, преданост пуна страхопоштовања према узвишености његовог чина. Он постаје биће очишћено од свакодневног живота, биће које постаје митско у својој суштини. То је идеалистички прототип нової човека. Мистик у епохи технике.

И најзад, треће: у униформи пилота, аутобиографски лик Клабундов проваљује у простор једне стварности чија оцена се колеба између демонског и инфатилног. Разлози нису само уметничке природе. Осуђујући кобну мешавину мита и масовне психологије, Клабунд је хтео да исмеје књижевни дискурс победе као последњу 
агонију политичког неоромантизма.

\section{Извори и литература}

Andrić, Ivo. Sabrana dela. Beograd (i dr.), Prosveta (i dr.), 1-17, 1981. Ball, Hugo. Flucht aus der Zeit. München 1927 [1914], cit. prema:

Ingold, Felix Philipp. Literatur und Aviatik. Europäische Flugdichtung 1909-1927. Frankfurt a. M. 1980, S. 215.

Benn, G. Die Dichtung braucht immer Spielraum, in: ,Börsenblatt', 6. Januar 1934

Bunjuel, Luis. Moj poslednji uzdah. Beograd, 2013, s. 48 (za Giljerma de Torea)

Crnjanski, Miloš. Putopisi I. Dela Miloša Crnjanskog, tom VIII, knjige 15n-19. Beograd : Zadužbina Miloša Crnjanskog, Bigz, SKZ; Lausanne: Lage d'Homme, 1995, I, 243.

Klabund. Der Marketenderwagen, Berlin, 1916, str. 122-124.

Klabund. Soldatenlieder. Gelber Verlag, München, 1916; erw. Neuauflage: Dragoner und Husaren. Die Soldatenlieder. Müller, München.

Niče, Fridrih. S one strane dobra i zla. Beograd, 1983, str.118.

Schlözer, August Ludwig von. Allgemeines Stats Recht und Stats Verfassungs Lere (2

Bde., 1793/1804). Vid. i: Neue Deutsche Biographie 23 (2007), S. 98-99.

Sombart, Werner. Händler und Helden: patriotische Besinnungen. München und Leipzig 1915.

Sontheimer, Kurt. Antidemokratisches Denken in der Weimarer Republik. München, 1992, str. 41.

Torre, Guillermo de. Historia de las literaturas de vanguardia. Madrid, 1945. 
Slobodan Grubačić

\author{
SIEGESDISKURSE IM VEXIERSPIEGEL \\ Zwischen Mythenüberlieferung und Massenpsychologie
}

Wie Gustav Le Bon, der mit seiner Studie „Psychologie des foules" 1895 die Massenpsychologie begründete, so beschäftigte auch den Expressionisten Klabund die Frage, welche Kräfte, welches Emotionalisierungspotential durch die unkritische Adoration eines Kriegsheimkehrers freigesetzt werden. Für Klabund ist der Flieger eine Chiffre für den Führer. Das „narrative Skandalon" dieser Prosa-Skizze liegt debei in der nicht präzise getroffenen Unterscheidung zwischen Wirklichkeit und Imagination. Klabund geht es nicht nur darum, verschiedene Formen des triebhaft Unbewussten, sondern auch elementare Machtmechanismen und Gefühlsstrukturen im Textsystem aufzudecken. 